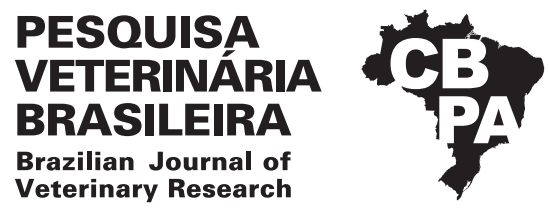

Pesq. Vet. Bras. 39(9):696-699, September 2019 DOI: 10.1590/1678-5150-PVB-6254

Original Article

ISSN 0100-736X (Print)

ISSN 1678-5150 (Online)

\title{
Necrohemorrhagic enteritis outbreak in a cattle feedlot in Nova Crixás, Goiás, Brazil ${ }^{1}$
}

\author{
Rafael C. Sanguanini² (D), Luna S. Girão ${ }^{2}$, Rodrigo Otávio S. Silva ${ }^{3}$, \\ Francisco Carlos F. Lobato ${ }^{3}$, Regiani N.G. Porto², Cairo Henrique S. Oliveira ${ }^{4}$ \\ and Veridiana M.B.D. Moura ${ }^{2 *}$ (D)
}

\begin{abstract}
Sanguanini R.C., Girão L.S., Silva R.O.S., Lobato F.C.F., Porto R.N.G., Oliveira C.H.S. \& Moura V.M.B.D. 2019. Necrohemorrhagic enteritis outbreak in a cattle feedlot in Nova Crixás, Goiás, Brazil. Pesquisa Veterinária Brasileira 39(9):696-699. Setor de Patologia Animal, Escola de Veterinária e Zootecnia, Universidade Federal de Goiás, Avenida Esperança s/n, Campus Universitário Samambaia, Goiânia, GO 74690-900, Brazil. E-mail: vdmoura@ hotmail.com

This study described an outbreak of necrohemorrhagic enteritis in a beef cattle feedlot in Nova Crixás, State of Goiás, Brazil, with emphasis on epidemiological, lesional, and laboratory aspects. Visits to the property were carried out and a necroscopic examination was performed on the bovine cadavers $(\mathrm{N}=57)$, which presented similar macroscopic alterations. Epidemiological data were collected, mainly referring to the feeding management of animals, and tissue samples were submitted to histopathological examination. Samples of feces and intestinal contents were also collected for bacterial isolation and PCR genotyping to detect the etiological agent, being confirmed Clostridium perfringens type A strains in 100\% of the samples. Furthermore, $33.3 \%$ of strains isolated from intestinal contents and $40 \%$ of those isolated from feces were positive for beta-2 encoding gene. Considering the history, macroscopic and microscopic findings, as well as bacterial isolation and PCR, the diagnosis of bovine necrohemorrhagic enteritis was determined.
\end{abstract}

INDEX TERMS: Necrohemorrhagy, enteritis, outbreak, cattle, feedlot, Goiás, Brazil, Clostridium perfringens, alpha toxin, hemorrhagic bowel syndrome, bovine.

RESUMO.- [Surto de enterite necro-hemorrágia em um confinamento de bovinos no município de Nova Crixás, Goiás, Brasil.] Descreve-se um surto de enterite necro-hemorrágica em um confinamento de bovinos de corte no município de Nova Crixás, Estado de Goiás, Brasil, com ênfase nos aspectos epidemiológicos, lesionais e laboratoriais. Foram realizadas visitas à propriedade e todos os cadáveres bovinos $(\mathrm{N}=57)$ foram submetidos ao exame necroscópico, os quais apresentaram alterações macroscópicas semelhantes. Foram compilados dados epidemiológicos, sobretudo referentes ao manejo

\footnotetext{
${ }^{1}$ Received on April 23, 2019.

Accepted for publication on May 7, 2019.

${ }^{2}$ Setor de Patologia Animal, Departamento de Medicina Veterinária, Escola de Veterinária e Zootecnia, Universidade Federal de Goiás (UFG), Avenida Esperança s/n, Campus Universitário Samambaia, Goiânia, GO 74690-900, Brazil. *Corresponding author: vdmoura@hotmail.com

${ }^{3}$ Laboratório de Bacterioses e Pesquisa, Departamento de Medicina Veterinária Preventiva, Escola de Veterinária, Universidade Federal de Minas Gerais (UFMG), Avenida Antônio Carlos 6627, Belo Horizonte, MG 31270-901, Brazil.

${ }^{4}$ Ministério da Agricultura, Pecuária e Abastecimento, Praça Cívica 100, 3o andar, Goiânia, GO 74003-010.
}

alimentar dos animais e amostras de tecido foram submetidas a exame histopatológico. Foram colhidas, também, amostras de fezes e conteúdo intestinal para isolamento bacteriano e genotipagem por PCR para detecção do agente etiológico, sendo confirmadas estirpes de Clostridium perfringens tipo A em $100 \%$ das amostras. Ainda, 33,3\% das cepas de Clostridium perfringens isoladas no conteúdo intestinal e $40 \%$ daquelas isoladas nas fezes foram positivas para o gene codificador da toxina beta-2. Considerando o histórico, os achados macroscópicos e microscópicos, o isolamento bacteriano e o PCR, foi estabelecido o diagnóstico de enterite necro-hemorrágica por C. perfringens tipo A.

TERMOS DE INDEXAÇÃO: Surto, enterite, necro-hemorragia, confinamento, bovinos, Goiás, Brasil, alfa toxina, Clostridium perfringens, síndrome do intestino hemorrágico.

\section{INTRODUCTION}

Bovine necrohemorrhagic enteritis is a clostridiosis caused by Clostridium perfringens type A strains (Goossens et al. 2016a), which presents necrotic and hemorrhagic lesions in the small intestine and sudden death of apparently healthy 
animals (Lebrun et al. 2010, Verherstraeten et al. 2013, Goossens et al. 2016a, 2016b, 2017). Although this disease presents a low morbidity and individual cases are observed sporadically, the high lethality, the rapid course to death, and the almost impracticable treatment confer economic importance to this disease in cases of outbreak, and prophylaxis should be prioritized (Lebrun et al. 2010, Goossens et al. 2016a, 2016 b, 2017). This study described an outbreak of bovine necrohemorrhagic enteritis in beef cattle feedlot located in Nova Crixás, Goiás, Brazil. Epidemiological, post mortem, and laboratory aspects of this disease are presented.

\section{MATERIALS AND METHODS}

A total of 57 deaths of cattle were observed from January to March, 2017 in a cattle feedlot in the municipality of Nova Crixás, Goiás, Brazil. All animals, although apparently healthy and with a good body score, presented sudden death without premonitory clinical signs associated with marked abdominal distension and accelerated putrefaction process. Anatomopathological examinations were performed on the corpses of the 57 dead animals, which presented the same pattern of lesions, characterized especially by small intestine loops of blackish red coloration and markedly distended due to the accumulation of a large amount of gas. The opening of the loops of the small intestine also showed a large amount of bloody fluid content and a diffuse and markedly hemorrhagic mucosa, showing streaks of blackish coloration (Fig.1). In addition, irregularities were verified in feeding times of animals, changes in diet composition, and large intervals between one supply and another of the ration up to 48 hours before death episodes.

After necropsy performed on fresh corpse of animal found dead, fragments of small intestine fixed in 10\% buffered formalin were sent for histopathological examination. Samples were processed according to routine techniques for paraffin embedding and histological sections were stained with hematoxylin and eosin (HE) and Gram techniques. In addition, three samples of intestinal contents and ten samples of feces, collected from three animals that died from March 19 th to 25th, 2017, were submitted for isolation and genotyping of Clostridium perfringens as previously described (Silva et al. 2016).

\section{RESULTS}

The histomorphologic evaluation of the small intestine showed marked edema, extending from the superficial stratum to the deepest part of the intestinal wall. The mucosa layer presented diffuse necrosis of the villi in association with hemorrhagic content and a marked mononuclear and polymorphonuclear inflammatory infiltrate. Gram-positive bacillary structures of diffuse distribution, consistent with Clostridium spp., were also observed in the mucosa layer. Some crypts were preserved, but with degenerate cells. Diffuse and marked edema was observed in the submucosa, as well as dilation of blood and lymphatic vessels (Fig.2). The muscular layers showed interstitial edema, degeneration, and necrosis of the myenteric plexus. In addition, bacterial isolation and PCR genotyping confirmed $C$. perfringens type A strains in $100 \%$ of the samples of intestinal contents and feces, of which 33.3 and $40 \%$ respectively, were beta- 2 positive. All the samples of intestinal contents had high bacterial counts $\left(>10^{6} \mathrm{CFU} / \mathrm{g}\right)$. In contrast, $20 \%$ of feces samples had high bacterial counts and the remainder presented counts of $10^{4} \mathrm{CFU} / \mathrm{g}$, which infers a microenvironment favorable to acute bacterial proliferation in the intestines of animals, resulting in the death of animals before high counts of bacteria could be seen in the feces. Based on the history, epidemiological pattern, histomorphologic findings, and microbiological results, the definitive diagnosis was necrohemorrhagic enteritis or hemorrhagic bowel syndrome.

\section{DISCUSSION}

Necrohemorrhagic enteritis in bovine is an important cause of sudden death (Lebrun et al. 2010, Verherstraeten et al. 2013, Goossens et al. 2016a). It occurs mainly in calves under an intensive breeding system, but this disease also affects adult animals. The main cause is a diet rich in proteins and carbohydrates, which, in excess, can overcome the digestive and absorption capacity of the digestive system of animals and, therefore, ends up serving as a substrate for the proliferation of Clostridium perfringens (Lebrun et al. 2010, Goossens et al. 2016a). During the period from January to March of 2017, there were five changes in the composition of the diet offered to the animals and the episodes of sudden death occurred up to 48 hours after its supply. However, abrupt changes in the regularity of feeding, delays in the ration distribution, and logistic intercurrences that involved large intervals without food available to the animals were related to episodes of sudden death due to necrohemorrhagic enteritis. Specifically, from March 18th to 19th, 2017, the animals remained 15 hours with the empty troughs, with 13 deaths on the two subsequent days. Stress due to sudden changes in diet composition and amount of food available is indicated as a predisposing factor to necrohemorrhagic enteritis, being observed from 24 to 36 hours before death (Lebrun et al. 2010, Verherstraeten et al. 2013, Goossens et al. 2016a). Transport of animals, regrouping, problems in the hierarchy or inappropriate management of animals are also pointed out as sources of stress (Lebrun et al. 2010, Goossens et al. 2016a). Stress causes reduction of peristalsis, leading to inadequate digestion and availability of nutrients that favor C. perfringens proliferation in the intestine (Allaart et al. 2013, Goossens et al. 2016a).

C. perfringens is a gram-positive, anaerobic, and spore-forming bacterium that is present in the environment and in the normal intestinal microbiota. However, situations of imbalance with an exacerbated proliferation of this bacterium are associated with diseases of the digestive tract. C. perfringens is a toxinogenic bacterium and its classification can be made according to the pattern of toxin production in type $\mathrm{A}, \mathrm{B}, \mathrm{C}, \mathrm{D}$, and $\mathrm{E}$ strains (Morris et al. 2012, Allaart et al. 2013, Verherstraeten et al. 2013, Goossens et al. 2016b, 2017). Isolation and genotyping of bacteria in the intestinal contents and feces of animals of this report evidenced only type A strains. This is consistent with the findings in animals with necrohemorrhagic enteritis, in which the isolates are almost exclusively from type A strains (Lebrun et al. 2010, Morris et al. 2012, Allaart et al. 2013, Goossens et al. 2016a, 2016b, 2017). However, there are controversies regarding the role of $C$. perfringens type A strains and their toxins in the pathogenesis of the disease.

Alpha toxin is the major toxin produced by type A strains. Studies have pointed out that alpha toxin is involved in the induction of lesions in the intestine, but its action may depend on the amount it is produced (Lebrun et al. 2010, Morris et al. 2012, Goossens et al. 2016a). Another theory states that this toxin triggers necrohemorrhagic enteritis by synergism with other toxins, such as a beta-2 (Lebrun et al. 2010) and perfringolysin 0 (Verherstraeten et al. 2013). Goossens et al. (2017) proposed that necrohemorrhagic enteritis occurs when there is an orchestrated action of toxins and enzymes produced by bacteria and their association with predisposing factors necessary to trigger the disease in the animal (Goossens et al. 2016a). This is consistent with the scenario observed in this 

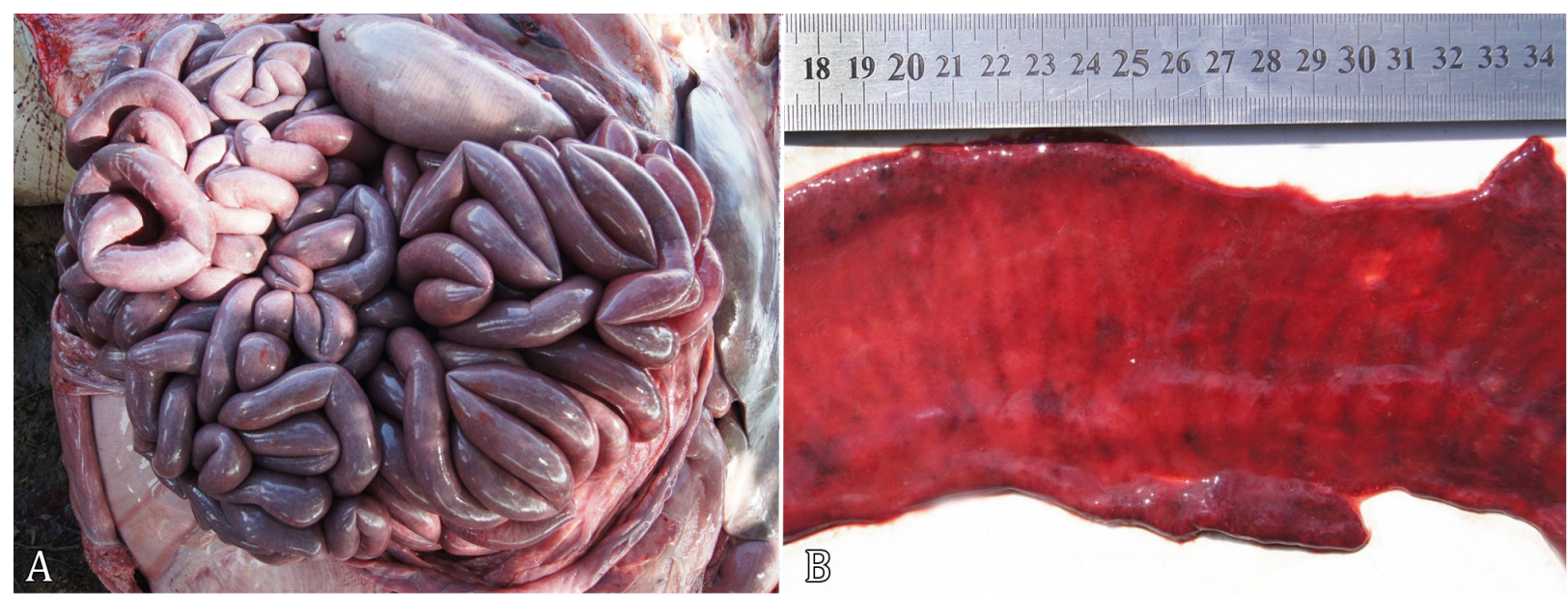

Fig.1. Small intestine, bovine. (A) Edematous, hemorrhagic small intestine distended by large amounts of gas within it. (B) Mucosa of the small intestine diffusely necrotic and hemorrhagic, as well as showing hemorrhagic streaks (vibices).

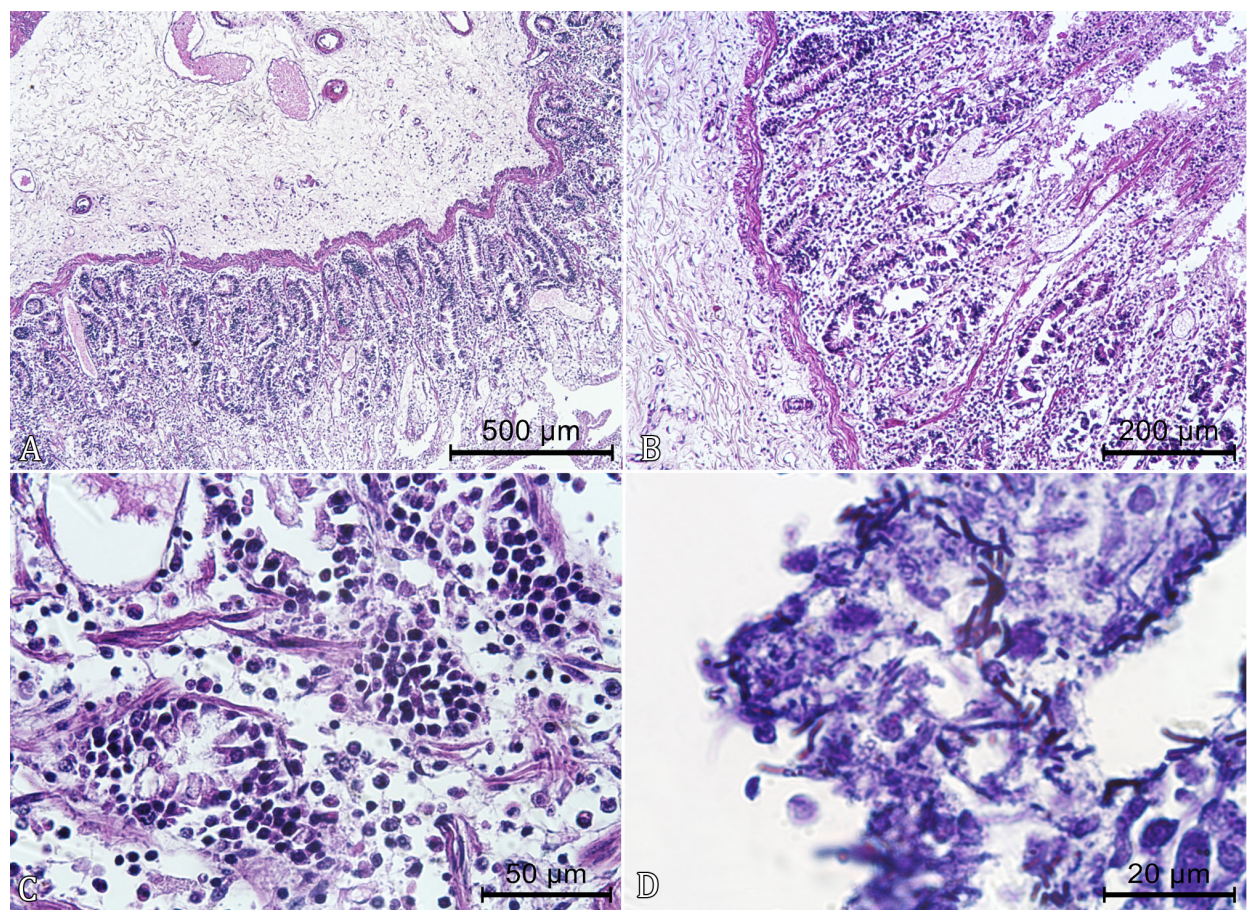

Fig.2. Small intestine, bovine. (A) Edematous submucosa with blood vessels filled with blood and discrete inflammatory infiltrate. HE, obj.5x. (B) Mucosa of the small intestine presenting villus necrosis and degeneration of crypt epithelium, in addition to a marked inflammatory infiltrate. HE, obj.10x. (C) Inflammatory infiltrate in the mucosa of the small intestine predominantly composed of mononuclear and rare polymorphonuclear cells. HE, obj.40x. (D) Gram-positive bacilli in the mucosa of the small intestine. Gram, obj.100x.

report, in which $C$. perfringens type A and positive for beta-2 encoding gene were isolated from feces and intestinal contents of animals found dead.

However, because $C$. perfringens type A strains are found in the intestinal microbiota of healthy animals, both bacterial isolation and toxin detection can be performed in the feces of healthy animals and hence have a little diagnostic value alone (Goossens et al. 2016a). Strains of $C$. perfringens are found at levels of $10^{2}$ to $10^{5} \mathrm{CFU} / \mathrm{g}$ of intestinal content in healthy animals. Higher counts, ranging from $10^{6}$ to $10^{8} \mathrm{CFU} / \mathrm{g}$, are related to animals with necrohemorrhagic enteritis. The best material for isolation, which has the highest amount of bacteria and reflects the exacerbated proliferation of clostridia, is the intestinal content from areas with necrohemorrhagic lesions (Lebrun et al. 2010). This explains why fecal samples showed counts compatible with healthy animals, while intestinal contents showed counts higher than $10^{6} \mathrm{CFU} / \mathrm{g}$, confirming the diagnosis of necrohemorrhagic enteritis. However, there is recent evidence that animals with the disease may have normal counts of $C$. perfringens type A even in intestinal contents. What is claimed is that predisposing factors provide an environment in which toxin production is regulated positively. This suggests that an increased toxin production and lesion development are not directly related to the exacerbated proliferation of the etiological agent (Goossens et al. 2016a). 
Regarding the macroscopic pattern of lesions, all the 57 animals exhibited lesions characteristic of necrohemorrhagic enteritis, including inflamed small intestine, distended due to gas accumulation, hemorrhagic and necrotic mucosa, abundant bloody fluid content, and rapid putrefaction of tissues in cadavers. In relation to the histopathological findings, mucosal layer with diffuse necrosis of the villi in association with a hemorrhagic content and marked inflammatory mononuclear and polymorphonuclear infiltrate are commonly described. Degeneration of the myenteric plexus and submucosal plexus may also be present (Lebrun et al. 2010, Goossens et al. 2016a), being only the first observed in this report.

\section{CONCLUSION}

On basis of the epidemiological data and findings from anatomopathological exams, an outbreak of necrohemorrhagic enteritis was determined. Adding tests of bacterial isolation and PCR genotyping, it was possible to find Clostridium perfringens type $A$ as the etiological agent involved, with positivity for beta- 2 toxin encoding gene. As showed, this condition can cause significant losses if food mismanagement of herds is present, with healthy animals evolving acutely to death.

Acknowledgments.- To the Animal Pathology Service of theSchool of Veterinary and Animal Science of UFG, to the Laboratory of Bacterial Diseases and Research of the School of Veterinary of UFMG and to CAPES, CNPq and FAPEMIG.

Conflict of interest statement.- The authors have no competing interests.

\section{REFERÊNCIAS}

Allaart J.G., Van Asten A.J.A.M. \& Gröne A. 2013. Predisposing factors and prevention of Clostridium perfringens associated enteritis. Comp. Immunol. Microbiol. Infect. Dis. 36(5):449-464. <http://dx.doi.org/10.1016/j. cimid.2013.05.001 ><PMid:23790636>
Goossens E., Verherstraeten S., Valgaeren B.R., Pardon B., Timbermont L., Schauvliege S., Rodrigo-Mocholí D., Haesebrouck F., Ducatelle R., Deprez P.R. \& Van Immerseel F. 2016a. The C-terminal domain of Clostridium perfringens alpha toxin as a vaccine candidate against bovine necrohemorrhagic enteritis. Vet. Res. 47(1):52-60. <http://dx.doi.org/10.1186/s13567-0160336-y> <PMid:27121298>

Goossens E., Verherstraeten S., Valgaeren B.R., Pardon B., Timbermont L., Schauvliege S., Rodrigo-Mocholí D., Haesebrouck F., Ducatelle R., Deprez P.R. \& Van Immerseel F. 2016b. Toxin-neutralizing antibodies protect against Clostridium perfringens-induced necrosis in an intestinal loop model for bovine necrohemorrhagic enteritis. BMC Vet. Res. 12(1):101-108. <http:// dx.doi.org/10.1186/s12917-016-0730-8><PMid:27297520>

Goossens E., Valgaeren B.R., Pardon B., Haesebrouck F., Ducatelle R., Deprez P.R. \& Immerseel F.V. 2017. Rethinking the role of alpha toxin in Clostridium perfringens-associated enteric diseases: a review on bovine necrohaemorrhagic enteritis. Vet. Res. 48(1):9-25. <http://dx.doi.org/10.1186/ s13567-017-0413-x><PMid:28209206>

Lebrun M., Mainil J.G. \& Linden A. 2010. Cattle enterotoxaemia and Clostridium perfringens: description, diagnosis and prophylaxis. Vet. Rec. 167(1):13-22. <http://dx.doi.org/10.1136/vr.167.1.12><PMid:20605954>

Morris W.E., Dunleavy M.V., Diodati J., Berra G. \& Fernandez-Miyakawa M.E. 2012. Effects of Clostridium perfringens alpha and epsilon toxins in the bovine gut. Anaerobe 18(1):143-147. <http://dx.doi.org/10.1016/j. anaerobe.2011.12.003><PMid:22178571>

Silva R.O., Almeida L.R., Oliveira Junior C.A., Lima P.C., Soares D.F., Pereira P.L., Silva I.J. \& Lobato F.C. 2016. Isolation and genotyping of Clostridium perfringens from free-living South American coati (Nasuanasua). J. Zoo Wildl. Med. 47(1):333-336. <http://dx.doi.org/10.1638/2014-0189.1> $<$ PMid:27010297>

Verherstraeten S., Goossens E., Valgaeren B.R., Pardon B., Timbermont L., Vermeulen K., Schauvliege S., Haesebrouck F., Ducatelle R., Deprez P.R. \& Immerseel F.V. 2013. The synergistic necrohemorrhagic action of Clostridium perfringens perfringolysin and alpha toxin in the bovine intestine and against bovine endothelial cells. Vet. Res. 44(1):45-52. <http://dx.doi. org/10.1186/1297-9716-44-45><PMid:23782465> 